\title{
The Influence of Vocabulary Mastery, Reading Interest, and Learning Motivation toward Translation Skill
}

\author{
Anam Sutopo ${ }^{1, *}$, Harun Joko Prayitno ${ }^{2}$ \\ ${ }^{1}$ English Education Department, Education Faculty, Universitas Muhammadiyah Surakarta, Indonesia \\ ${ }^{2}$ Indonesian Education Department, Education Faculty, Universitas Muhammadiyah Surakarta, Indonesia
}

Received June 29, 2019; Revised October 30, 2019; Accepted November 6, 2019

Copyright $\odot 2020$ by authors, all rights reserved. Authors agree that this article remains permanently open access under the terms of the Creative Commons Attribution License 4.0 International License

\begin{abstract}
The purpose of this study is to know whether or not there is a positive and significant influence of vocabulary mastery, reading interest and learning motivation toward translation skill. This study applied a quantitative approach. The population of this study was 285 while the sample was 175 students who taken by cluster random sampling. The techniques for collecting data were test and questionnaire. The collected data were analyzed by using SPSS version 21.0. The result of the research shows that vocabulary mastery, reading interest and learning motivation have a positive and significant influence toward translation skill.
\end{abstract}

Keywords Vocabulary Mastery, Reading Interest, Learning Motivation, and Translation Skill

\section{Introduction}

Language is very important as the tool for communication among people. Language is also the media for sharing the idea. Without using language well, usually people are easy to make misunderstanding from one to another. There are many languages used by people around the world for making communication, including English. People should understand English for communicating one to another [1]. It means that people may use English for developing science and technology because of its development which grow up quickly. In another hand, English can be used as one of the bridges to make better life in this global interaction, including Indonesian.

In Indonesia, English becomes the foreign language. English has been learned by the students since Elementary School (ten years old) until University level (twenty five years old). There are four skills that should be mastered by the Indonesian learners, namely speaking, listening, writing and reading. Listening and reading are the difficult and important skills. It means that both skills, especially reading, are important ones for the students. Students who have a good reading skill can develop their potency to understand the contents and information.

Meanwhile, people and students who have not mastered English can get real problems in understanding and getting messages from the English text. Thus, translation is one of the alternative solutions for helping them. Translation activity enables the English text to be translated into Indonesian one [2]. It means that the role of translation in developing the science and technology is also very significant. It may help people to understand the material trough reading the translated text.

Translation is not an easy task [3]. This statement shows that translation is not only crossing the two languages or more, because it needs some factors influencing the result or quality of translation. Those factors are vocabulary acquisition, learning motivation, reading ability, writing skill and the background knowledge of the text to be translated [4].

Translation needs a critical attention [5]. It means that the core of translation is transferring 'meaning' or 'message' from the source language (SL) into the target language (TL). The translator must be careful in transferring message from SL into TL accurately. Thus, it is common to see "gain and lose" of the meaning in translation since it does not change the message. The translator is able to seek the most similar meaning between the source text (ST) and the target text (TT). The translator should keep the excess and mission in the source language then they may transfer it into the target text [6]. When the translator has translated well semantically, but they cannot move to the closer mission, and then the result of translation is not good. The translator has spent their time and energy carelessly. So, to avoid this useless activity and to have a nice work, the translator should not only consider the linguistics aspect and text to be translated but also to think the translation theory [7]. 
Vocabulary acquisition supports the translator competence for translating the material. Usually when student have mastered the advanced vocabularies, the process of their translation could be easier [8]. Vocabulary mastery may influence the translator in doing the task. Vocabulary mastery may help translator in doing the translation result ${ }^{8}$. Motivation may also support the process of translation [9]. Having a high motivation may run the translation activity smoothly. The motivated students usually are able to change the impossible to possible result. It means that students can work successfully. In translation, the motivated translators may start working on translation well.

In reading skill, the translator begin finding the main idea, getting the message, determining specific meaning, stating the purpose of the passage and getting reference and making inference. From the reading process, comprehending the text is the important step for the translators, even students. After mastering SL well, the students may improve their reading and writing skill in TL. It means that students can improve the translation skill in order to transfer the message from SL to the TL accurately.

Therefore, the students of the sixth semester of English Education Department, Universitas Muhammadiyah Surakarta (UMS) should master the four skills especially reading and writing because they belong to the skills needed in translation process. If the students can catch the message sent by the author, they are able to understand and catch the hidden meaning in the SL, and then they can get the main message of the text. That is why writers choose the translation skill as the object of this study.

So, the success of translation, especially in line with translation process, can be influenced by many components within the individual. Those components may come from both inside and outside of the students; including linguistic and non-linguistic components. The intrinsic and extrinsic can prevent the students from reaching the success in language learning [10]. The extrinsic factor may come from teachers, learning material, classroom condition, and all social cultural factors, while the intrinsic factors include all personality factors within an individual like self-appreciation, inhibition, risk taking, anxiety, and motivation. Besides, the components influencing translation skill are vocabulary acquisition, grammatical judgment, translation theories and another part of language that is needed to support the success in doing translation activity.

There are four components in translation skill. They are mastering the source language, mastering the target language, getting meaning (message), and understanding the knowledge background of the material that will be translated. It means that the reading and writing skills are very needed. The second language reading is affected by vocabulary [11]. The extent of vocabulary is represented as the high mastery of vocabulary size, referring to the number of words learned by the learners. The vocabulary is fundamental in the earliest stage of the vocabulary acquisition [12]. Vocabulary is the basic knowledge in learning English by which the students may find the message from text easily. Furthermore, to master vocabulary the students are expected to be able to translate the source text into another text and it is not difficult for them to grasp the messages found in the source text.

Another component affected translation skill is reading interest. Most of the materials presented in the textbook or another written text is in line with reading. The students having a high reading interest will easily understand or having broader perspectives in certain issues [13]. Students are interested in English first before they start reading a text. When they have been interested in reading English text, they may start actively in learning process of reading and also they are able to give feedback quickly to their need if they are interested in the materials. The interest has a very strong positive influence on reader's comprehension and considers the factors that have been found in increasing reader's situational interest [14]. The interest is also one of the main factors influencing the students reading activity and supports the students in reading activity as well as translation exercises. So, the students need reading interest when doing translation.

Another aspect that may affect students' success in mastering translation skill is students' motivation. Motivation is one of the important components having a great influence to the success of students' language learning. The motivation is another key to be successful in reading [15]. The main reason is that the students have a great motivation; the students are expected to know the message of text fully. Therefore, when the students read English text frequently and they have a great motivation in learning English, they are capable to gain the translation skill. The low or high of students' motivation in learning English may influence the result of their translation. The high motivation has motivated and encouraged students to put all of their power in mastering English subject and doing translation work.

Related to the explanation above, the writers took the students of sixth semester of English Education Department, UMS to be tested because the writers assume that the students in this semester already have advanced vocabulary level of English that enables them to follow the program. The fact shows that during pre-observation, the lecturer of translation subject said that most of the students of sixth semester of English Education Department in UMS can translate well and had a little problem in catching reading text, although most of them have mastered vocabulary. Some of students are not familiar with reading activity, thus affecting their motivation to learn translation in necessary. It is due to the translation activity needs a great motivation to do so. Motivation may change the power of students to be brave enough and stronger in doing many activities, including reading comprehension and translation exercises. There are two kinds of students' 
characteristics [16]. First, learners get bored easily. Second, they forget something quickly. On another hand, lack of vocabulary in learning English text may greatly influence their interest in reading English text. It also makes the students' learning motivation low; the impact is they have difficulties in doing translation work.

In another words, it can be highlighted that if the students have high learning motivation, very good vocabulary acquisition, and reading interest, they feel confident enough in learning process and they may get better result in translation. Therefore, the writers want to find out the fact and the students of sixth semester of English Education Department, UMS in 2017/2018 academic year is chosen as the focus of this study.

Based on the above explanation, the writers are interested in testing the hypothesis of the study that says whether or not there is a positive significant influence on students' learning motivation, students' vocabulary mastery, and students' reading interest toward translation skill for the students of sixth semester of English Education Department, UMS in 2017/2018 academic year.

\section{Research Method}

This study applied the type of correlation study in the form of quantitative approach. The writers used correlation method because the writers want to know the influence of one variable on other variables. The population of this study was the 285 students of sixth semester of English Education Department, UMS in 2017/2018 academic year. The writers used cluster random sampling to get the representative sample from an amount of 175 students. This cluster random is needed to make more effective the in conducting this research. As the quantitative paradigm, that the writers may apply using the cluster random to fulfill the representativeness. The data of this research are collected through questionnaire and test. The questionnaire is used for collecting the data in term of reading interest and students' motivation. In carrying out the questionnaire, the writers applied close-type questionnaire consisting of questions that must be answered by respondents themselves and there were several answers available, and the respondents only choose the most relevant one. The questionnaire consists of the indicators of each variable. The total of the questions on reading interest is 20 and the question on learning motivation is also 20 in the form of positive and negative statements. Test may be used for getting the data in line with students' vocabulary mastery and students' translation skill. The test consists of the indicators of each variable both vocabulary mastery and translation skill. The amount of question on vocabulary mastery test is 40 items and the questions on translation skill test are 40 items too. The writers applied multiple choices test because it is easier to get the data in line with the students' vocabulary mastery and translation skill.

In justifying the students' score, this study applied
Guttman scale of measurement. It is used with some elements which can be ordered in a hierarchical manner as the representative of the respondents; extreme "attitude" of this research. It also may be inferred that respondents who agree to the statement, would have agreed also to the other statements. Each statement may have the corresponding weight associated with it. Then, the writers applied Likert scale category in scoring. The writers also conducted a try-out first to gain the validity and reliability before all of the instruments to be tested for the sample.

Finally, the obtained data were analyzed by using the following steps: getting the result of mean and standard deviation as the descriptive of the data, then doing the classic assumption testing. They used normality, linearity, multicollinearity, and heteroscedasticity. Next, the writers analyzed the multiple regressions. Finally, the writers carried out the test to answer the hypothesis with uses T-test, F-test, coefficient influence, and effective influence and relative influence. The writers applied SPSS version 21.0 to analyze the data to find the result of classic assumption, multiple regressions, and hypothesis testing.

\section{Result and Discussion}

\section{A. Descriptive Statistic}

Firstly, the data in line with students' learning motivation $\left(\mathrm{X}_{3}\right)$ were collected by using a close-type questionnaire consisting of extrinsic motivation and intrinsic motivation. The result shows that the mean score is 2.96 and the standard deviation is 0.82 . Generally, the students of sixth semester of English Education Department, UMS in 2017/2018 academic year often have motivation for learning. Based on the mean result of the indicators of the students' learning motivation, the extrinsic motivation is higher (3.04) than intrinsic motivation (2.92). It means that $6.5 \%$ of them never get motivation for learning, 23\% respondents sometimes get motivation for learning, $32.5 \%$ of them often get motivation for learning, and $38 \%$ of them always get motivation for learning. From the result above, the indicator that has the highest percentage of never and sometimes is intrinsic motivation with $29.5 \%$ (never $6.5 \%$ + sometimes $23 \%$ ). Then, the indicator which has the highest percentage of often and always is extrinsic motivation with $70.76 \%$ (often $32.5 \%$ + always $38 \%$ ).

The second, the data of students' vocabulary mastery $\left(\mathrm{X}_{1}\right)$ was also collected by using multiple choices test consisting of word classes and phrase aspects of meaning. The result shows that the mean score is 2.93 and the standard deviation is 0.41 . Generally, the students of sixth semester of English Education Department, UMSin 2017/2018 academic year have a good mastering in English vocabulary. From the indicators of students' vocabulary mastery, the students have the highest mastering in word classes and phrases with the mean value of 0.72 . Besides, $30.6 \%$ of them have sufficient mastering 
in English vocabulary, and $69.4 \%$ have a good mastering in English vocabulary. From the result above, the indicator word classes and phrases are of higher percentage than aspect of meaning. It can be understood that the percentage of the indicator of word classes and phrases $69.4 \%$ for the correct answer while $30.6 \%$ for the wrong answer by the students. Next, the percentage of the indicator of aspect of meaning is $74.5 \%$ for the correct answer and $25.5 \%$ for the wrong answer by the students.

The third, the data of students' reading interest $\left(\mathrm{X}_{2}\right)$ were collected by using a close-type questionnaire which consists of pleasure, willingness, consciousness, and attention. These indicators are divided into ten item numbers of statements with four optional answers by using Likert scale category. Therefore, it can be seen that the maximum score is 40 and the minimum score is 10 . The result shows that the mean score is 3.17 and the standard deviation is 0.83 . Generally, the students of sixth semester of English Education Department, UMSin 2017/2018 academic year have often interested to read English text. From indicators of the students' reading interest, the consciousness has the highest mean of 3.18 and pleasure has the lowest mean of 2.76 . It means that $5 \%$ respondents have never been interested in reading English text, 19.5\% respondents are sometimes interested in reading English text, $40.5 \%$ of them often have interest in reading English text, and $35 \%$ of them are always interested in reading English text. From the result above, the indicator which has the highest percentage of indicator of never and sometimes is consciousness with $24.5 \%$ (never $5 \%+$ sometimes $19.5 \%)$. Then, the highest percentage of indicator of often and always is attention with $75.5 \%$ (often $40.5 \%$ + always $35 \%)$.

Finally, the last variable is students' translation skill (Y) including identifying the main idea, finding detail, vocabulary in context, reference, and inference. These indicators are summed up into twenty numbers with four optional answers which has score 0 until 40 from total correct answer multiplied by two. The result shows that the mean score is 2.97 and the standard deviation is 0.49 . Generally, the students of sixth semester of English Education Department, UMSin 2017/2018 academic year have a good translation skill. From five indicators in this variable, the identifying transferring message has the highest mean of 0.83 , and acceptability has the lowest mean of 0.67 . It means that $17.5 \%$ of them have bad translation skill, and $82.5 \%$ have an excellent translation skill. From the result above, the indicator which has the highest percentage is transferring message with $83 \%$ for the correct answers and $17 \%$ for the wrong answer by the students. Then, the lowest percentage is acceptability with $70.2 \%$ for the correct answer and $29.8 \%$ for the wrong answer by the students.

\section{B. Classic Assumption Testing}

The result of normality testing by using Kormogorov-Smirnov shows that the probability values are more than 0.05 as follows: students' vocabulary mastery $\left(\mathrm{X}_{1}\right)$ is 0.057 ; students' reading interest $\left(\mathrm{X}_{2}\right)$ is 0.083 ; students' learning motivation $\left(\mathrm{X}_{3}\right) 0.141$; and students' translation skill( $\mathrm{Y})$ is 0.068 . It means that the data distribution is normal.

The linearity result shows that the probability values of students' vocabulary mastery $\left(\mathrm{X}_{1}\right)$ is 0.118 ; students' reading interest $\left(\mathrm{X}_{2}\right)$ is 0.073 ; and students' learning motivation $\left(\mathrm{X}_{3}\right)$ is 0.527 . It means that the result of each variable is more than 0.05 so the writers conclude that the data is linear.

The result of the multicollineariry is seen from the tolerance value and inflection factor (VIF). The tolerance values of each variable are as follows: students' vocabulary mastery $\left(\mathrm{X}_{1}\right)$ is 0.941 ; students' reading interest $\left(\mathrm{X}_{2}\right)$ is 0.867 ; and students' learning motivation $\left(\mathrm{X}_{3}\right)$ is 0.893 ; which are the each value $>0.10$. It means that students' vocabulary mastery, students' reading interest, and students' learning motivation simultaneously contribute translation skill. Then, the result of variance inflection factor (VIF) value of each variable is students' vocabulary mastery $\left(\mathrm{X}_{1}\right)$ is 1.1084 ; students' reading interest $\left(\mathrm{X}_{2}\right)$ is 1.176 ; and students' learning motivation $\left(\mathrm{X}_{3}\right)$ is 1.118 ; which are the each value $<10$. It means that the independent variables have contributed to translation skill. The writers conclude that the independent variables in this study do not have serious problem with the other independent variables. It means that they are working together to support the dependent variable.

The probability values of heteroscedasticity testing are that: students' vocabulary mastery $\left(\mathrm{X}_{1}\right)$ is 0,290 ; students' reading interest $\left(\mathrm{X}_{2}\right)$ is 0.822 ; and students' learning motivation $\left(\mathrm{X}_{3}\right)$ is 0.86 . It can be understood that all significant value all of independent variables are more than 0.05 . The writers assume that there is no heteroscedasticity in regression model.

\section{Multiple Regression}

The results of regression coefficient for independent variables are that: students' vocabulary mastery $\left(\mathrm{X}_{1}\right)$ is 0.754 ; students' reading interest $\left(\mathrm{X}_{2}\right)$ is 0.207 ; and students' learning motivation $\left(\mathrm{X}_{3}\right)$ is 0.213 . The constant value of the regression is 7.356. Then, the formulation of multiple regression is $\mathrm{Y}=7.356+0.754 \mathrm{X}_{1}+0.207 \mathrm{X}_{2}+$ $0.213 \mathrm{X}_{3}$. It means that:

1) If the variables students' vocabulary mastery, students' reading interest, and students' learning motivation are 0 , students' translation skill becomes 7.356 .

2) If the variable students' vocabulary mastery increases one point while the variables students' reading interest and students' learning motivation are assumed constant, the increment of students' translation skill is 0.754 .

3) If the variable students' reading interest increases one point while the variables students' vocabulary mastery 
and student's learning motivation are assumed constant, the increment of students' translation skill is 0.207 .

4) If the variable student's learning motivation increases one point while the variables students' vocabulary mastery and students' reading interest are assumed constant, the increment of translation skill is 0.213 .

\section{Hypothesis Testing}

The last step in the analysis of the data in this study is hypothesis testing. The result of multiple regressions is used to find out the result hypothesis testing. The first, result of regression coefficient of students' vocabulary mastery $\left(X_{1}\right)$ is 0.754 . The result of $t_{\text {result }}$ is higher than $t_{\text {table }}$ $(10,225>1.960)$. The significant value of this variable is 0.000 , less than 0.05 . Second, result of regression coefficient of students' reading interest $\left(\mathrm{X}_{2}\right)$ is 0.207 . The result of $t_{\text {result }}$ is higher than $t_{\text {table }}(2.265>1.960)$. The significant value of this variable is 0.023 , less than 0.05 . Third, result of regression coefficient of students' learning motivation $\left(X_{3}\right)$ is 0.213 . The result of $t_{\text {result }}$ is higher than $\mathrm{t}_{\text {table }}(2.548>1.960)$. The significant value of this variable is 0.012 , less than 0.05 .

Moreover, based on the calculation of F-test, it shows that the result of $F_{\text {result }}$ is higher than $F_{\text {table }}(36.622>2.68)$. The significant value is 0.000 ; less than 0.05 .

Based on the analysis of coefficient determination, the result of $\mathrm{R}^{2}$ is 0.408 . It means that the positive significant influence of all the independent variables in this study namely students' vocabulary mastery, students' reading interest, and students' learning motivation toward dependent variable is students' translation skill of the students of sixth semester of English Education Department, UMS in 2017/2018 academic year is $60.8 \%$, while $39.2 \%$ is influenced by other factors that are not discussed in this research. The other factors above could be the personality, discipline, and availability resources or others.

Summary of Effective Influence (Ec) and Relative Influence (Rc)

\begin{tabular}{ccc}
\hline Variables & $\begin{array}{c}\text { Effective } \\
\text { Influence (EI) }\end{array}$ & $\begin{array}{c}\text { Relative } \\
\text { Influence(EI) }\end{array}$ \\
$\begin{array}{c}\text { Students' Learning } \\
\text { Motivation }\end{array}$ & $7.5 \%$ & $13.7 \%$ \\
$\begin{array}{c}\text { Student's Vocabulary } \\
\text { Mastery }\end{array}$ & $27.3 \%$ & $68.2 \%$ \\
$\begin{array}{c}\text { Student's Reading } \\
\text { Interest }\end{array}$ & $26 \%$ & $18.1 \%$ \\
Total & $60.8 \%$ & $100 \%$ \\
\hline
\end{tabular}

\section{E. Discussion}

The calculation result shows that there are positive and significant influences of students' vocabulary mastery, students' reading interest, and students' learning motivation toward students' translation skill. The result of F-test analysis was found that $F_{\text {result }}$ is higher than $F_{\text {table }}$ $(38.422>2.68)$. The significant value is 0.000 ; it is less than 0.05 . Then, the influence of all independent variables on dependent variable can be seen from the coefficient of determination (R2), where the value of R2 is 0.408 . It means that the influence value of all independent variables in this study are students' vocabulary mastery $\left(\mathrm{X}_{1}\right)$, students' reading interest $\left(\mathrm{X}_{2}\right)$, students' learning motivation $\left(\mathrm{X}_{3}\right)$ toward dependent variable is students' translation skill (Y) is $40.8 \%$, which means that students' translation skill get significant contribution from students' vocabulary mastery $\left(\mathrm{X}_{1}\right)$, students' reading interest $\left(\mathrm{X}_{2}\right)$, students' learning motivation $\left(\mathrm{X}_{3}\right)$ while $39.2 \%$ is influenced by other factors. This result is consistent with Zhu Ming [17] Noels, K. A. at all [18] Taboada, A.[19], Faliyati [20] which stated that individually students' vocabulary mastery, students' reading interest, and students' learning motivation have a positive and significant influence toward students' translation skill.

Statistically, the percentage of students' vocabulary mastery is $73.4 \%$. Hence, by mastering vocabulary the students are able to improve their understanding of reading English text and also have a good command in communication [21]. This variable has two indicators; they are word classes and phrase, and word meaning. From the result above, the word classes and phrase have higher percentage with $73.8 \%$, including noun, noun phrase, verb, verb phrase, adverb, adverbial phrase adjective and adjective phrase, and aspect of meaning is $72.9 \%$ including synonym and antonym. Based on the result of T-test that is $t_{\text {result }}$ is higher than $t_{\text {table }}(10.225>1.960)$. The significant value of this variable is 0.000 , less than 0.05 . Then, the influence value of $X_{1}$ variable toward $Y$ variable can be seen from the result of effective influence (EI) and relative influence (RI). It is found that the effective influence (EI) given by students' vocabulary mastery is $27.3 \%$ and relative influence (RI) is $68.2 \%$. This result is consistent with Chen, K.Yu [22] and Farvardin and Mansoor [23] who state that vocabulary mastery of students have positive influence on enhancing the students' achievement in translation skill. Therefore, students' vocabulary mastery is very important. The students who have high vocabulary acquisition can see how to recognize letters, how to implement in the context clues, how to write in details, how to transfer the message of a longer passage, how to describe, evaluate, and show the author's meaning, so they will be easier in answering the questions of students' translation skill test.

Statistically, the percentage of students' reading interest is $75.5 \%$. Interest is one of the strong psychological components in a person that can influence in learning achievement [24]. It can be understood that the students' reading interest has an important role for the students who are able to increase translation skill. The highest percentage of indicator is attention consisting of $82.1 \%$; it belongs to often and always category. Another indicator giving the influence in reading interest belonging to often and always category are: pleasure with $66.9 \%$, willingness with $78.1 \%$, and the last consciousness with $74.9 \%$. Based on the result of the T-test, the regression coefficient is 
0.204 , with the result of $\mathrm{t}_{\text {result }}$ is higher than $\mathrm{t}_{\text {table }}(2.292>$ 1.960 ). The significant value of this variable is 0.023 , less than 0.05 . Then, the influence value of $X_{2}$ variable toward $\mathrm{Y}$ variable can be found in the result of effective influence (EI) and relative influence (RI). It also can be understood that the effective influence (EI) given by students' reading interest is $10.6 \%$ and relative influence (RI) is $18.1 \%$. This result is consistent with Zurina [25] which stated that interest in reading text can influence the students' achievement. The students with their interest in reading text can comprehend the information which is in the various types of texts. In other words, by having interest in reading text, it will be easier for the students to get good translation skill, because they have good skill in understanding the text.

Statistically, the percentage of students' learning motivation is $70.6 \%$. In foreign language learning, the students who have high learning motivation can make good achievement [26]. In other word, learning motivation can influence the students to get success in learning English language. The extrinsic motivation has higher percentage of $75.6 \%$, which consists of easy work, pleasing teacher, and dependence on lecturer and it belongs to often and always category. While, the indicator of intrinsic motivation also give the influence on learning motivation with $34.5 \%$, which consists of challenge, curiosity, and independent mastery, and it belongs to never and sometimes category. Based on the T-test result, it can be found also that the regression coefficient of students' learning motivation $\left(X_{3}\right)$ is 0,219 . The result of $t_{\text {result }}$ is higher than $t_{\text {table }}(2,546>1,960)$. The significant value of this variable is 0.012 , less than 0.05 . Then, the influence value of $\mathrm{X}_{3}$ variable toward $\mathrm{Y}$ variable can be seen from the result of effective influence (EI) and relative influence (RI). It can be understood that the effective influence (EI) given by students' learning motivation is $7.5 \%$ and relative influence (RI) is $13.7 \%$. This result is consistent with Fadillah [27] which stated that learning motivation can influence the students' translation skill. Students' learning motivation is an important factor which can used to get the success in English learning. Besides, based on the result of this study it can be assumed that students' learning motivation can improve their quality in English learning, because they have spirit and commitment to enhance their competence in learning English language.

\section{Conclusions}

Based on the result of the study and discussion above, the writers may conclude that there is a positive and significant influence of students' learning motivation, students' vocabulary mastery, and students' reading interest toward students' translation skill. It can be proved from the result of F-test that is higher than $\mathrm{F}_{\text {table }}(38.422>$ 2.68 ) and significant value is $0.000<0.05$. It means that the students' vocabulary mastery, students' reading interest and students' learning motivation simultaneously toward students' translation skill. There is a positive and significant influence of students' vocabulary mastery toward students' translation skill. There is a positive and significant influence of students' reading interest toward students' translation skill. There is a positive and significant influence of students' learning motivation toward students' translation skill.

Based on the conclusion above the effective influence of all independent variables: students' vocabulary mastery $\left(\mathrm{X}_{1}\right)$, students' reading interest $\left(\mathrm{X}_{2}\right)$, and students' learning motivation $\left(\mathrm{X}_{3}\right)$ toward dependent variable that is students' translation skill (Y) is of $60.8 \%$. Hence, the lecturer should consider the students' learning motivation by using a various creative methods and techniques. Besides, the lecturer selects the material which is not boring and must relate to their goal in translation activity.

\section{REFERENCES}

[1] Muklas., M. "Talking Chips Technique To Teach Speaking". Journal of English Language Education and Literature, Vol. II No. 12017

[2] Tejasurya, DP., Suharjito. "Model of Mobile Translator Application of English to Bahasa Indonesia with Rule-Based and J2ME. International Journal of Communication \& Information Technology (CommIT) http://msi.binus.ac.id/commit/ Vol. 8 No. 1 Mei 2014, pp. 28-34

[3] Sutopo. Anam, "Terjemahan dan Penerjemahan dalam Lintas Pemahaman”, Surakarta: Jasmine Press, 2015.

[4] Suzane, H. "Interest, Reading, and Learning. Theoretical and Practical Considerations". Educational Psychology, Vol 13 (3): P. 191-209. 2001.

[5] Sutopo. Anam. "Penerjemahan Naskah Resmi", Surakarta: MUP Press, 2016.

[6] Francoise, G. "Developing Reading Skills", Cambridge: Cambridge University Press, 2011.

[7] Benny, H. "Ideologi dalam Penerjemahan". Jakarta: Pustaka Ilmu, 2004.

[8] Kuang Yu, C. "The Impact of EFL Students' Vocabulary Breadth of Knowledge on Literal Reading Comprehension", Asian EFL Journal, Vol. 51, April 2011.

[9] Reza, Muhamad. "The Realtionship between Students' RedainG Motivation and Reading Comprehension", Jounal of Education and Practice. ISSN: 2222. Vol.4 No 18. 2013.

[10] Brown, D. H., "Teaching by Principles: An Interactive Approach to Language Pedagogy", New York: Addison Wesley Longman, Inc. 2001.

[11] Laufer, B. "Comparing focus on form and focus on forms in second-language vocabulary learning". The Canadian Modern Language Review, 63 (1), 149-166. 2006. 
[12] Hulstijn, J.H. "Mnemonic methods in foreign language vocabulary learning". In J. Coady and T. Huckin (Eds.). Second Language Vocabulary Acquisition. Cambridge: Cambridge University Press. pp. 203-224. 1997.

[13] Khairuddin, Z. “A Study of Students' Reading Interests in a Second Language". International Education Studies, Vol. 6 , No. 11: P. 160-170, 2013.

[14] Suzane, H. "Interest, Reading, and Learning. Theoretical and Practical Considerations". Educational Psychology, Vol 13 (3): P. 191-209. 2001

[15] Grabe, W., \& Stoller, F. L. "Teaching and Researching Reading”. Harlow: Pearson Education Ltd. 2002.

[16] Rahayu, W. T. "A Correlation Study between Students' Motivation and Students' Vocabulary Mastery Toward Reading Comprehension". Thesis. Surakarta: IAIN Press. 2015.

[17] Zhu, Ming., T'he Study of Student Motivation on English Learning in Junior Middle School -- A Case Study of No.5 Middle School in Geji English Language Teaching, Vol. 6, No. 9: P. 136-145. 2013.

[18] Noels, K. A. at all. "Why Are You Learning a Second Language? Motivational Orientations and Self Determination Theory". Attitudes, Orientations, and Motivations in Language Learning: Advances in Theory, Research and Applications. Ed. Dörnyei, Z. Malden (USA): Blackwell. 33-63. 2003

[19] Taboada, A., "Relationship of General Vocabulary, Science Vocabulary, and Student Questioning with Science Comprehension in Students with Varying Levels of English Proficiency", Springer: College of Education and Human Development, George Mason University, 2012.

[20] Faliyati, Eva. "The Correlation between Students' Vocabulary Mastery and Their Interest in English toward Reading Comprehension in Descriptive Text". Premise: Journal of English Education. Vol. 4. No. 2. 68-76. ISSN 2089-3345. 2015.

[21] Rie, K. "Relationships between Productive Vocabulary Knowledge and Speaking Performance of Japanese Learners of English at the Novice Level". A Dissertation Submitted to the University of Tsukuba in Partial Fulfillment of the Requirements for the Degree of Doctor of Philosophy in Linguistics. 2015.

[22] Chen, K. Yu. "The Impact of EFL Students' Vocabulary Breadth of Knowledge on Literal Reading Comprehension". Asian EFL Journal, Vol. 51. 2011.

[23] Favardin, M.T and Mansoor, K. "The Role of Vocabulary Knowledge in Iranian EFL Students' Reading Comprehension Performance: Breadth or Depth?" Theory and Practice in Language Studies, Vol. 1, No. 11, pp. ISSN. 1575-1580. 2011.

[24] Ainley, M. "Interest, Learning, and the Psychological Processes That Mediate Their Relationship". Journal of Educational Psychology. Vol. 94, No. 3, 545-561. 2002.

[25] Zurina, K. "A Study of Students' Reading Interests in a Second Language". International Education Studies; Published by Canadian Center of Science and Education. Vol. 6, No. 11; ISSN 1913-9020. 2013.
[26] Riswanto, A and Aryani, S. "Learning Motivation and Student Achievement: Description Analysis and Relationships both". COUNS-EDU: The International Journal of Counseling and Education. Vol.2, No.1, pp. 42-47. ISSN: 2548-348X. 2017.

[27] Fadillah, R. "Learning Motivation and Students' English Achievement". Jurnal Penelitian Humaniora, Vol. 15, No. 2, pp. 89-98. 2014. 